Philosophy and Progress: Vols. LIX-LX, January-June, July-December, 2016 ISSN 1607-2278 (Print), DOI : http://dx.doi.org/10.3329/pp.v59i1-2.36682

\section{RAMMOHUN ROY: A STUDY OF HIS RELIGIOUS VIEWS}

\section{Milton Kumar Dev ${ }^{*}$}

The making of modern Bengal largely synchronized with the religious view and contributions of Rammohun Roy, the 'first Modern Bangalee’. Rammohun Roy (1772-1833), the precocious child of Bengal and the first in a long series of great leaders of thought and action, blazed a trail in setting up nineteenth century religious, social and political reform movements. Backed by a robust intellect and a high degree of rational view, the dynamic personality of Rammohun Roy as Tagore put it, 'Vitalized our national being with the urgency of creative endeavour and launched it into the arduous adventure of self-realization. He is the great path-maker of this country, who has removed ponderous obstacles that impeded our progress at every step.' (Das and Mahapatra, 1996, p. 61) 'Rammohun stands forth 'as the tribute of new Bengal'. (Collet, 1913, p. 155)

\footnotetext{
* Associate Professor, Department of History, University of Dhaka Email-devmiltonkmr@yahoo.com
}

Rammohun was the precursor of the religious view in the nineteenth century Bengal. His favourite authors at Patna are said to be the Sufi philosophers whose teachings were greatly influenced by the Vedanta philosophy. Besides, Rammohun had come in contact with Muslim scholars during the formative period of his life. This enabled him to imbibe some kind of rationalism inherent in Islamic thought without, however accepting the orthodoxy of Islamic religious dogma. Similarly, although he had acquired a profound knowledge of Hindu religious scriptures, the critical outlook which he had developed led him to refuse to accept what appeared to be the irrational aspects of Hindu religion. (Ahmed \& Chowdhury, 2004, p. 147)

Rammohun Roy's religious view undoubtedly created a good deal of controversy during his life-time and after. Neither a prophet nor a saint of spiritual fact, very learned Rammohun entered the premises of religion vigorously and secularly. Rammohun was a multisided editor of religion adequately qualified for the job. For he was a master of several languages - Sanskrit, Hindi, Bengali, Persian, Arabic, Hebrew, Greek and English. He studied, in their originals, the Upanishads and the Tantras, and the old and the new testaments, and he was in touch with the orientalists of his day. Rammohun, in a remarkable letter to the Minister of Foreign Affairs of France wrote in 1831:

It is now generally admitted that not religion only but unbiased commonsense as well as the accurate deductions of scientific research leads to the conclusion that all mankind are one great family of which numerous nations and tribes existing are only branches. Hence enlightened men in all countries feel a wish to encourage and facilitate human intercourse in every manner by removing as far as possible all impediments 
to it in order to promote the reciprocal advantage and enjoyment of the whole human race. (Sarma, 1944, p., 204)

He thus struck a note of universal religious view which is the most distinguishing note of Hindu Renaissance of the nineteenth century. Born in an orthodox Hindu family and receiving proper education with secular motives, he as a 'kulin' Brahman, was married three times before puberty. (Chattopadhay, 1379 B. S. p. 12)

A tremendous editor, reader, prolific writer, philanthropist, agitator, dignified ambassador and orator, Rammohun after 1814 was dazzling enough to be regarded as the heralder of the modern age in Bengal by generations of scholars. A close review of Roy's first remarkable work (C. 1803-04) entitled Tuhfat-ul- Muwahiddin (A Gift to Deists), a book written in Persian but with a preface in Arabic makes it clear that the young questioner was dissatisfied with every religion. In this work he not only denounced traditional Hindus worship of idols but made the bold assertion that "falsehood is common to all religions without distinction.” (Ahmed \& Chowdhury, 2004, p. 148) He further declared that the realization of the existence on one 'Supreme Power' could be attained by individuals without instruction or guidance from any one. (Ibid, p. 147) Tuhfat-ul-Muwahiddin was a protest against idolatry and superstition in all religions and an attempt to find a universal religion based on the unity of Godhead. Moreover, a Hindu Brahman, as he was, his Quranic, Hebraic and Biblical studies could not but be secularly oriented. The scion of Shakta-Vaishnavite parentage he studied the Vedic literature superfluously and, therefore, perhaps with considerable secular outlook. Besides, he traveled in the remotest parts of the world and made comparative assessments of their religious practices and beliefs. (Obaide, 1973, p. 3) In propounding his theory of comparative religion, Roy was primarily influenced by the ideas of seventeenth and eighteenth centuries - the age of rationalism and enlightenment in the West. Thus, Christian theology and philosophy and Western ideas and institutions had their impact on him, when he preached the religious view of monotheistic spiritualism and universal humanism for the Hindus.

From 1820 to 1823 to 1823 Rammohun was engaged in a controversy with Christian Missionaries on the fundamentals of Christianity. This controversy started with the publication of his book - the precepts of Jesus, the Guide to peace and happiness, in which he tried to separate the moral teachings of Jesus from the historical and miraculous accounts given in the gospels. Rammohun's religious view and writings influenced the younger generation of his time. (Das \& Mahapatra, 1996, p. 94) He was the first modern man to rise above current belief, and prejudices and extend his view to a distant horizon, far beyond the general conception of time. (Majumdar, 1972, p. 19) He must have been working particularly on Hindu Religious texts ever since. From 1815, the first year of Rammohun's permanent residence in Calcutta to 1819 we get sixteen of his works, published on the Vedanta in different languages. He found Hindus in general more superstitious and miserable both in performance of their rituals, and in their domestic concerns, than the rest of the known nations on the earth. He mentioned, "they [Hindus] were with few exceptions, immersed in gross idolatry and in belief of the most extravagant descriptions respecting futurity, antiquity and the miracles of their deities and saints.” (Das \& Mahapatra, 1996, p. 111)

In the very first year of his residence in Calcutta, Rammohun established the Atmiya Sabha carry on deliberations on the 
essence of religion. Rammohun's earlier friends and aspirants like Dwarakanath Tagore, Prasannacoomar Tagore, Brindabon Mitra, Baidyanath Mukhopadhaya and Hariharananda Tirthaswami and some other new friends started to attend its sessions. Ramamohun found his first inspiration for religious new view from the animated discussions in this Sabha. (Ganguly, 1381 B. S, p. 14)

Rammohun was the first personality to be vocal against the prevalent Hindu religious practices and doctrines, which were injurious both to the social living of the people as well as to their growth of individuality. His religious new thinking and views were directed principally against two current features of Hindu profession and practice - polytheism and Idolatry. (Bhattacharya, 1995, p. 32) This involved him in an exciting debate carried on through the press and discussions held at different places. (Ibid, p. 65)

It was the strongest believe of Rammohun that social advancement depended upon reformation of religious beliefs and practices. (Das \& Mahapatra, 1996, p. 111) No doubt, he was the first cosmopolitan religious thinker of modern Bengal. He accepted eternal principles from all religions and desired to fuse them into one integrated whole for the welfare of the humanity. He perceived that the universal truth was stressed in different ways and different accents in its different historic utterances. The Vedantas, which had restored him to faith, he always considered as strongest in Jnana, the knowledge of the unity of all souls and of the world in Brahma; Islam, which had given him his early iconoclastic zeal, he considered as strongest in the sense of divine government, and Christianity, which gave him the Divine Exemplar, which he considered as strongest in the ethical and social guidance to peace and happiness in the path of life. (Ibid, p. 111)
Rammohun never tried to introduce a new religion, though he had extensive study on religion and theology. Rammohun's stand for opposition to Hindu idolatry and polytheism were that the authentic version of the Hindu religion available in the Vedas was not followed in the current polytheistic and idolatrous practices, that the current practices (Child-sacrifice, Sati, Hookswinging etc) were based on bad understanding of the true purport of the Vedas, that the current practices indicate a decline of true scholarship of the scriptures; and, lastly that the current practices became the vested interests of a selfish priestly class who were less interested in the people's true wellbeing and moral progress than in that of keeping them under their own influence. In 1811, Rammohun heard at Rangpur that his brother Jugmohun died and that his wife, whom Rammohun held in high esteem, was burnt along with him. He was shocked and took a vow that he would never rest till this inhuman custom was abolished. He not only wrote tracts against Sati but also organized vigilance committees whose duty it was to be present whenever there was a case of sati and see that no force was employed and that the government regulations on the subject were strictly observed. Roy began his campaign against 'Sati' in 1818 and succeeded in getting the support of a government regulation, prohibiting the evil custom in 1829. Even after passing of the law, when the orthodox section of Hindus sent up a petition against the order, Rammohun arranged for a counter -petition supporting the action of the Governor General, and also organized a congratulatory address to Lord Bentinck. He sought the support of the foreign rulers to check the evil rituals by means of progressive legislation and in this sphere, he was the forerunner of later religious reformer such as Vivekananda. It is notable to mention here that what Rammohun wrote in the introduction to the Ishaupanishad published in 1816: "Hindus of the present 
time, with a very few exceptions, have not the least idea that it is to the attributes of the Supreme Soul as figuratively represented by shapes corresponding to the nature of those attributes, they offer adoration and worship under the denomination of gods and goddesses.” He further wrote, "under these impressions, therefore, I have been impelled to lay before them genuine translations of parts of their Scripture, which inculcates not only the enlightened worship of one God, but the purest principles of morality, accompanied with such notices as I deemed requisite to oppose the arguments employed by the Brahmins in defense of their beloved system.” (Ghosh, 1816, pp. 77-79)

Earlier it is mentioned that Rammohun had a cosmopolitan religious view. And he developed a universal outlook towards religion. By the foundation of a religious association - the Brahmo Sabha (later Samaj) in 1828, Rammohun made direct attacks against the abuses and evils of Hinduism. (Ahmed \& Chowdhury, 2004, p. 148) The Trust Deed of the Brahmo Sabha embodied the following important provisions: (1) the Sabha would be a place of public meeting for all without any distinction of creed for the worship of Brahmo - the Supreme Being from whom all human souls oriented and rejoined after death; (2) no sacrifice or rituals to permitted on the Sabha buildings; (3) no form of idol, image, painting or portrait was to be admitted within the Sabha buildings.

So, Rammohun was of opinion that religion and divine worship were very personal matters of a person unjustly controlled by priest class. Idolatry was against shastras, ethics and social well being. He asserted that God was omnipresent and is the supreme Being. Brahmo Sabha consisted first in meditating on God with the help of the Gayatri Mantra and some texts from the Upanishads and a few explanatory verses. This meditation was followed by stotra taken from the Mahanirvana Tantra.
Despite many shortcomings and weaknesses in their socioreligious system, the educated Hindus, under the leadership of Brahmo Sabha, did not embrace Christianity, but tried to introduce reforms to purify Hinduism by getting rid of its crudities and the pure stream of Hindu monotheism. This has been analysed as follows:

Men of the type of Rammohan Roy could not, and did not, shut their eyes to the superiority of Christianity from the ethical point of view. They despised in their hearts the idols, as worshipped by the vulgar; they saw through the pretensions of their priests and had long learnt to doubt the efficacies of their sacrifices. But their social institutions were so intimately interwoven with their religion that it required no small amount of moral courage openly to break with it, and to lose caste, that is, to become estranged from all relations, friends and acquaintances. But while they clearly perceived that their religion was behind time, they were by no means inclined to admit that from a philosophical point of view it was inferior to Christianity. (Muller, 1952, p. 59)

In his life Rammohun was apparently impressed by the ethics of Christianity and Islam. He found the doctrines of Christ more conductive to more principles and better adapted for the use of rational beings. Besides, he derived from Islam the idea of monotheism and also his iconoclastic hatred against idolatry. That is why it will make no wrong to say that Roy always took care to guard his Islam-like monotheism for the formless monism of the Vedanta. Believing in a monotheistic personal God he always focused on the utility of prayer, repentance and selfless social service, which are not enjoined in the Vedanta. Perhaps, for this reason Kishori Chand Mitra termed him a 'theo-philanthropist. (Mitter, 1845, p. 388)

Rammohun gave the concept of a Universal religion based on monotheism. His announced purpose was to restore the Hindu 
faith to its original purity. ${ }^{22}$ To establish the truth of his statement Rammohun always used to quote the famous sloka of Brihaspati:

“Kevalam Sastramashritya Na
Kartavyo Arthamirnaya
Buddhineena Vicharena
Dharmahamih Prajayate.”

(Das \& Mahapatra, 1996, p. 109)

Rammohun never pretended to set up any separate communal religious order. His was an attempt of spiritual unification of the Hindus as well as of all mankind on the basis of available similarity in spiritual views of different peoples and different periods. This unification is often referred to, as a synthesis of Hindu, Islamic and Anglo-European cultural traditions. But Rammohun's synthesis was different; it implied discrimination and systematic choice, directed by the two standards of 'reason' and 'social comfort' which recur so often in his works.

From the above discussion of Rammohun's religious view vis$a$-vis popular Hinduism, Christianity, Islam and Vedanta and it will transpire that he derived ideas from them but always reshaped those ideas in accordance with his utilitarian purpose best fitted to his period. The aim was in no way spiritual but evidently concerned with the secular sphere of life. He ultimately chose the Vedanta as his principal ideological foothold and religions view.

It is interesting to note that Remmohun had a Muslim lady love. For this issue he was accused if adultery by his orthodox opponents. To this matter his response was that his affairs with the lady was legal and sacred as they were married in the Saiva style. (Bandyopadhyay and Das, 1380 B.S, PP. 3-4) He described that if marriage with the mantra of the god Brahma is evaluated as sacred and legal, why should the marriage with the mantras of another equally significant god siva should not be regarded as so. However, Roy was tagged by the later Brahmons', Unitarians and the Tantrik Hindus as their own made term, a 'formidable mulla', a 'Hindu protestant', 'father of comparative religion' and so on. In fact, Rammohun's hard work brought him deserved fame during his life time; but his religious view which attempted to reform Hindu religion hardly yielded any countable result. He was such a man whose religious view had been rudely rejected by his country, which refused to be reminded of the responsibility of its great inheritance while clinging with desperate infatuation to its degeneracy. But his view was urgent, and therefore his appearance in the midst of an angry annoyance was inevitable. The partial failure of Rammohun was due to his secularism in religious view. Imperfect as a religion in the traditional sense his religious view presented a lot of nontraditional ideas pertinent to secularism and impertinent to religion. This ambivalent experiment was bound to fail at least as a spiritual exercise called religious. This-worldliness and avoidance of everything supernatural marred the prospect of his religious view being popular. The secular aspect of his activities was appreciably successful, and the Hindu society accepted many of his social and cultural views. But so far as religious view is concurred, his so-called followers had later imported many things unsecular to build a new religious order (Brahmo Samaj), And the then distressed Hindus craving for a higher religion was later satisfied by the truly seer Sri Ramakrishna Paaramhansa (1836-1886), The great nineteenth century saint of Bengal. Sri Ramakrishna attained an exalted state of spiritual illumination that had never before been achieved by any religious genious in Bengal or elsewhere. (General report, 2012, p. 1) Ramakrishna's mission was the edification of all 
embracing eternal Hinduism, rather thas the discriminatory expulsion of symbolism and idol-worship. But we must not forget that Rammohun was very successful to bring an end with the 'Sati' a manmade ritual in Bengal. The Bengal Harkara, tried to evaluate the role of Rammohun in the agitation against the Sati in an editorial stated: "Let us not, therefore offer our exclusive praise and gratitude either to Rammohun or Lord William Bentinck. The former would never have succeeded in his patriotic and enlightened labours without the co-operation of the latter, nor would Lord Bentinck has ventured on so desirable a measure, if the mind of the natives had not been prepared to abandon the worst of superstitions by the unwearid labour of their distinguished country man.” (Das and Mahapatra, 1996, p. 111) Of Rammohun's impact on the modern period in Bengal, let Rabindranath Tagore's memorable words bear testimony: 'It takes time to understand and appreciate any rare personality who comes at an age when his country has lost itself and contradicts its own majesty. His voice sounds painfully discordant only because the people have allowed the strings of their own instrument to slacken and fail to make them harmonise with the views of truth which once originated in the sublime height of their nature; (Tagore, 1966, P.56). These are reasonable and fair assessment of the contribution of Rammohun to the Religions reform movement of nineteenth century in Bengal. Finally, we may state that his religious views remain a thought-provoking piece in the history of Bengal and of Hinduism at the juncture of the eighteenth and the nineteenth centuries. Rammohun was no doubt, a great personality who fearlessly advocated the necessary changes in religion which the circumstances of his age demanded. But he was also a great conservative who remained faithful to the best traditions of his country.

\section{References}

1. Das, H., and Mahapatra. S., (1996). The Indian Renaissance and Raja Rammohan Roy, Jaipur: Pointer Publishers

2. Collet, S. D., (1913). Life and Letters of Raja Rammohan Roy, Calcutta: A. C. Sarkar \& Company

3. Ahmed, A. F. S., and Chowdhury, B. M., (2004). Bangladesh: Nation Culture and Heritage, Dhaka: Independent University, Bangladesh

4. Sarma, D. S., (1944), Studies in the Renaissance of Hinduism in the Nineteenth and Twentieth centuries, Benares: The Benares Hindu University, India.

5. Chattopadhay, N., (1379 B. S.). Mahatma Raja Rammohun Rayer Jivancharit, Calcutta: De’s reprint

6. Tuhfat-ul- Muwahiddin, translated by Moulavi Obaidullah el obaide, reprinted in Ninetieth Century Studies, No. 1, 1973, Calcutta, p. 3. Introduction

7. Majumdar, R. C., (1972). On Rammuhan Roy, Calcutta: The Asiatic Society

8. According to Vedanta, each soul is potentially divine

9. 1815 : (1) Vedantagrantha (Bengali).

(2) Vedantagrantha (Hindustani translation).

1816 : (3) Vedantasara (Bengali).

(4) Vedantasara (Hindustani translation).

(5) Kenopanishat (Bengali translation).

(6) Translation of Kenopanishat (English).

(7) Ishopanishat (Bengali translation).

(8) Translation of Ishopanishat (English).

(9)Translation of an Abridgement of the Vedanta (English).

1817: (10) Kathopanishat (Bengali translation).

(11) Mandukyapanishat (Bengali translation)

(12) Auflosung des Wedant (German).

1819: (13) Mundakopanishat (Bengali translation). 
(14) Translation of the Mundakaopanishat (English)

(15) Translation of the Kathaupanishat (English).

(16) Atmanatmaviveka of Sankaracharya (Bengali)

10. Ganguly, P. C., (1381 B. S). Atmiya Sabhar Katha (in Bengali). Calcutta, p. 14

11. Bhattacharya, S. (1995), The Bengal Renaissance: Social and Political Thought, Calcutta, c. Publication.

12. Ghosh, J. C. (1816) Ishaupanishad, Calcutta

13. Mitter, K. C. (1845), in Calcutta Review

14. It is not correct to find out the meaning of any text depending only on the Shastras. The Dharma Suffers if one has recourse to a method of analysis which has dispensed with rationalism.

15. Bandyopadhyay, B., and Das, S. K., (eds.). (1380 B. S). Rammohan Granthabali Part IV, $3^{\text {rd }}$ ed., Calcutta

16. The General Report of the Ramakrishna Math and Ramakrishna Mission. (2012), Howrah, India, RKM

17. Tagore, S., (1966). Raja Rammohun Roy, Makers of Indian Literature, New Delhi, Sahitya Akademi 